\title{
Seasonal Variation in the Ignition Time of Redberry Juniper in West Texas
}

\author{
STEPHEN C. BUNTING, HENRY A WRIGHT, AND WALTER H. WALLACE
}

\section{Abstract}

Seasonal variations in the moisture content, relative humidity, and average daily mean temperatures in the month preceding an ignition treatment were highly correlated to the length of preheating time required for ignition of green redberry juniper leaves during dry years. Ether extractives had no significant effect on ignition of green juniper leaves. During wet years, no correlation was found between any of the variables measured and ignition of green foliage. The data indicated that ignition was more easily predicted when the precipitation was below average than when it was above average, and that ether extract content was not a factor in ignition under either moisture regime.

Procedures have been described by Wright (1974) for the prescribed burning of dozed juniper (Juniperus spp.) Burning live standing juniper, however, is more difficult. The dense overstory of juniper of ten prevents the development of an understory. Understory vegetation, particularly grass, is necessary to enable a low intensity fire to carry across an area. High intensity fires necessary to remove the live juniper burn as crown fires and are difficult to control. It has been observed in the field during prescribed burning that the flammability of living redberry juniper (Juniperus pincho$t i i$ Sudw.) varies depending on the season of the year. This study was conducted to determine what effect ether extract and foliage moisture content had on the fla mmability of green redberry juniper foliage.

Anderson (1970) suggested that flammability consists of 3 components: ignitibility, sustainability and combustibility. Ignitibility was defined as the ignition delay time. Similar methods for determining the latter 2 components were not formulated.

Several studies have attributed to the change in flammability of plant tissue primarily due to changes in the fuel moisture content (Hawley 1926, Curry and Fons 1938, Fons 1946, Rothermel and Anderson 1966). Other research, however, showed that the flammability of ponderosa pine (Pinus ponderosa Laws) and Douglasfir (Pseudotsuga menziesii (Mirb.) Franco) increased even though moisture content of the foliage also increased (Philpot and Mutch 1971). They speculate that an increase in flammability coincides with an increase in ether extract content of the foliage.

Ether extracts are a broad group of chemical compounds, such as waxes, oils, terpenes, and fats, that are present in plant tissue in varying amounts. Some do not, however, require the complex pyrolytic reactions prior to combustion of other carbohydrate compounds (Philpot 1969a, Rothermel 1976). It has been reported that some compounds char when heated at the expense of the flammable volatiles (Rothermel 1976) and these do require pyrolysis. Susott (personal communication 1979) found that approximately $60 \%$ of the total heat of combustion in conifer needles is released as volatile products at $500^{\circ} \mathrm{C}$. The other $40 \%$ remains as

Authors are assistant professor, College of Forestry, Wildlife and Range Sciences, University of Idaho, Moscow 83843; Horn Professor, Department of Range and Wildlife Management, Texas Tech University, Lubbock 79409; chemist, Intermountain Forest and Range Experiment Station, Northern Forest Fire Laboratory, Missoula, Montana 59801 .

This report is a contribution of Texas Tech University, College of Agriculture Sci. No. T-9-245; University of Idaho, College of Forestry, Wildlife and Range Sci. No. 188.

Manuscript received October 27, 1980 char residue. Flaming combustion is fed by the gasses released while the char is more likely to burn by glowing combustion. For these reasons, ether extracts should play a major role in the flammability of fuels, the rate of spread and intensity of fires (Philpot 1969a). Montgomery (1976) also found that even though ether extracts were a minor fraction of the organic compounds found in the Mediterranean-type shrubs, their special burning characteristics influenced fire behavior.

A number of studies have researched the effect of ether extracts on plant flammability. It has been shown that chemically dried manzanita (Arctostaphylos pungens H.B.K.) does not burn as readily as untreated manzanita even though the fuel moisture was lower (USDA 1963). The dried foliage contained about one half the ether extract content of the untreated foliage. Philpot (1969b) showed that the burning rate of aspen (Populus tremuloides Michx.) leaves to be directly proportional to ether extract content. Other research has shown that the removal of ether extracts from pine needles and sphagnum moss can lower piloted ignition time (Mutch 1964).

Seasonal variation of terpene compounds in redberry juniper has been studied (Adams 1970) but was not related to flammability. Adams found that the content of most terpenes was least in the winter months and the variation between trees was greatest in the summer. This variation was attributed to differential growth and metabolic rates between trees.

\section{Methods and Study Area}

The study was conducted in Garza County, Texas, in a stand that was dominated by redberry juniper. The understory consisted of a mixture of short and mid grass species such as little bluestem (Schizachyrium scoparium (Michx.) Nash), sideoats grama (Bouteloua curtipendula (Michx.) Torr.), blue grama (B. gracilis (Willd. ex H.B.K.) Log. ex Griffiths) and buffalograss (Buchloe dactyloides (Nutt.) Engelm.). The site receives an average $480 \mathrm{~mm}$ of precipitation annually, occurring primarily in the late spring and early fall.

At monthly intervals, from June, 1973, to April, 1975, approximately $250 \mathrm{~g}$ foliage samples were collected from 6 redberry juniper trees ( 3 male, 3 female). A portion of the sample from each tree was divided into 3 subsamples. Each subsample contained from 20 to $30 \mathrm{~g}$ dry weight of foliage. The subsamples were heated with a modified propane torch. The torch was modified by adding a spiralled piece of copper tubing to the outlet. Holes drilled into the tubing $2.54 \mathrm{~cm}$ apart and $0.8 \mathrm{~mm}$ in diameter developed a relatively constant temperature of $440^{\circ} \mathrm{C}$ above the flame. The foliage was not allowed to come in contact with the flame. The time of preheating prior to ignition was recorded. An average of three subsample preheating times for each tree was calculated and used in the data analysis.

The unburned foliage remaining from each tree after the ignition trials was immediately placed on dry ice to prevent loss of ether extractives by volatilization. The sample was freeze-dried and analyzed for ether extract content by the method described in American Society for Testing and Materials (1956) and Philpot (1969a). Karl Fischer Titration (ASTM 1962) was used to deter- 
mine the amount of moisture not removed by the freeze-drying process. Ether extract content was calculated on a dry weight basis.

Average daily maximum, minimum and mean temperature for the month preceding sampling was determined from U.S. Weather Bureau records from Post, Texas. Relative humidity, ambient temperature and foliage moisture content data were collected at the time of burning.

Multiple regression and Pearson's correlation coefficients (Snedecor and Cochran 1967) were used to analyze the data. Ether extract, temperature, moisture content, wind and relative humidity

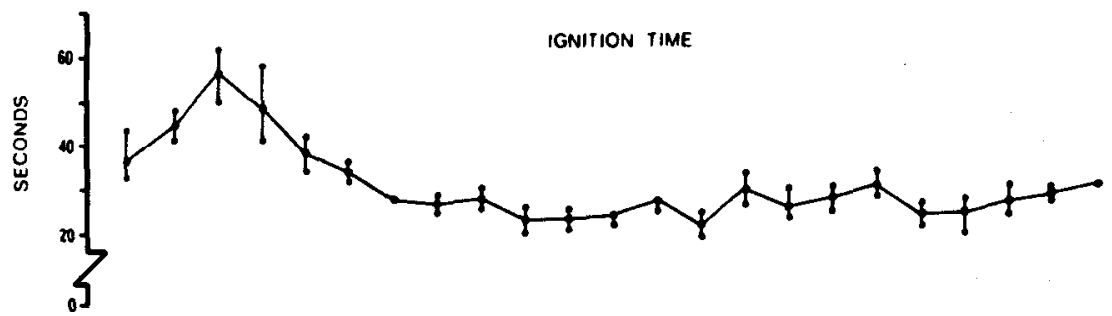

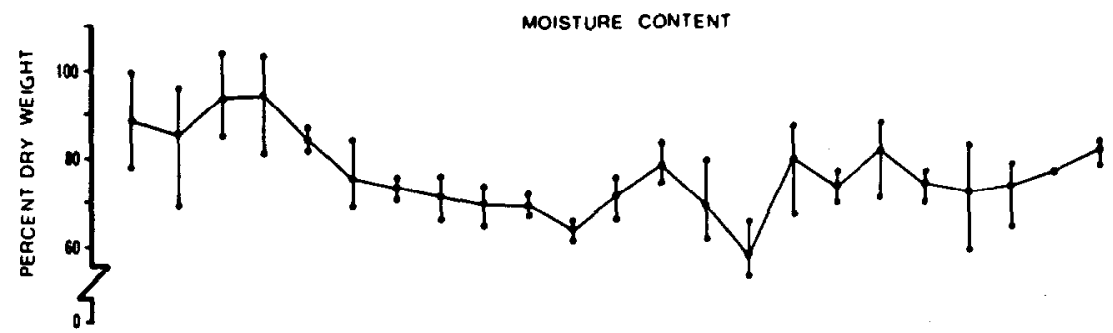
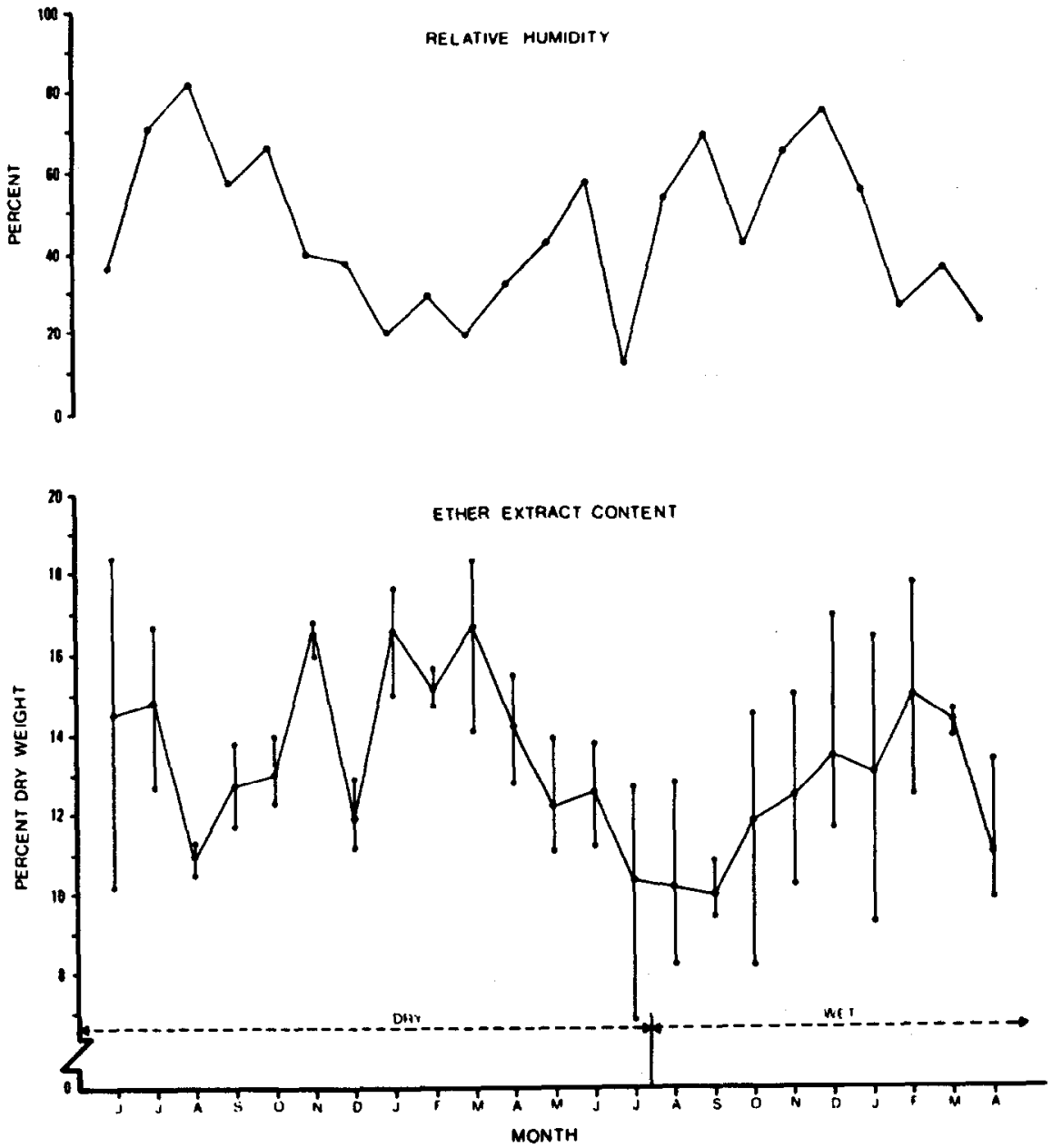

Fig. 1. Change in ignition time, moisture content, relative humidity and volatile oils in juniper foliage in re lation to month (June, 1973 to April, 1975). 
were used as independent variables to predict ignition time.

\section{Results and Discussion}

The data revealed that the ignition times of the female trees varied widely both between and within samples on a given date. This variation was attributed to the presence of the fruit on the foliage. The fruits were high in moisture and oils, and the numbers and stage of development varied considerably between trees. For this reason the analysis of the data was restricted to the male trees.

Analysis of the data by multiple regression indicated that moisture content of the foliage and the average daily mean temperature for the month preceding sampling were the most significant variables for predicting juniper ignition, accounting for $61 \%$ of the variation. The correlation coefficients were 0.73 and 0.48 for moisture and temperature, respectively. The equation is as follows:

$$
\mathrm{Y}=-.23 .96+0.56 \mathrm{X}_{1}+0.19 \mathrm{X}_{2}
$$

where $Y$ is the ignition time (sec), $X_{1}$ is the moisture content of the foliage (percent dry wt.) and $X_{2}$ is the average daily mean temperature during the month preceding sampling. Correlation coefficients for the other temperature variables (ambient air temperature, average daily maximum temperature and average daily minimum temperature) were also significant (Table 1), but were highly correlated to average daily mean temperature. The equation indicates an increase in ignition time with increasing moisture content and average daily mean temperature. Normally, one would expect ignition time to decrease with increasing air temperature.

During the period from June, 1973, to July, 1974, precipitation was below average and from August, 1974, to April, 1975, precipitation was above average. Analyzing these periods separately revealed different results. During the dry period the most significant variables were moisture content of foliage and relative humidity. The correlation coefficients were 0.83 and 0.77 , respectively. The prediction equation for this time period is:

$$
Y=-19.70+0.54 X_{1}+0.24 X_{2}
$$

where $Y$ is the ignition time, $X_{1}$ is the moisture content and $X_{2}$ is the relative humidity. This equation accounts for $79 \%$ of the total variation.

Analysis of the data collected during the wet period showed no significant correlations. The best two variables, moisture content and average daily maximum temperature for the month preceding sampling, could account for only $33 \%$ of the total variation. Field observations support the conclusion that fire behavior is more difficult to predict during wet periods.

Moisture content of foliage and relative humdity can be effectively used to predict the ignition time of redberry juniper during dry periods. During wet periods, however, the ignition time is difficult to predict using the variables measured.

Increased ether extract content of foliage has been shown to relate to increased flammability and burning rates (Mutch 1964, Philpot and Mutch 1968, Philpot 1969b). This, however, was not significantly correlated to ignition of redberry juniper. If anything, increasing ether extract content decreased the ignition time (Table 1). The reason for the discrepancy is unknown but could be due in part to the way researchers define flammability. Flammability in the study was defined as the length of preheating time required before ignition. In the study by Philpot and Mutch (1968), it was defined as the burning rate. In other studies, however, flammability has been considered to be the time required for total combustion of fuel. An experiment testing the effect of ether extractives on the two processes, ignition and combustion rate, may resolve the contradiction in the literature.

Ether extract content increased to a maximum during January through March and decreased to a minimum during July and August (Fig. 1). This does not agree with Adams (1970) but the discrepancy may be due to low terpene content in ether extractives of juniper. Both of these periods are normally the drier time of the
Table 1. Correlation coefficients for each of the independent variables in

\begin{tabular}{|c|c|c|c|}
\hline \multirow[b]{2}{*}{ Independent variables } & \multicolumn{3}{|c|}{ Correlation coefficient } \\
\hline & Dry year & Wet year & Combined \\
\hline \multicolumn{4}{|l|}{ Data at time of burning } \\
\hline $\begin{array}{l}\text { Percent moisture content } \\
\text { (\% dry wt) }\end{array}$ & $0.826^{* *}$ & -0.356 & $0.731 * *$ \\
\hline $\begin{array}{l}\text { Ether extract content } \\
(\% \text { dry } w t)\end{array}$ & -0.167 & -0.314 & 0.170 \\
\hline Air temperature & 0.153 & 0.303 & 0.247 \\
\hline Relative humidity & $0.772^{* *}$ & -0.318 & $0.472^{* *}$ \\
\hline \multicolumn{4}{|l|}{ Weather for preceding month } \\
\hline $\begin{array}{l}\text { Mean daily maximum } \\
\text { temperature }\end{array}$ & $0.467^{* *}$ & 0.390 & $0.45 I^{* *}$ \\
\hline $\begin{array}{l}\text { Mean daily minimum } \\
\text { temperature }\end{array}$ & $0.598 * *$ & 0.200 & $0.490^{* *}$ \\
\hline $\begin{array}{l}\text { Mean daily average } \\
\text { temperature }\end{array}$ & $0.549 * *$ & 0.248 & $0.480^{* *}$ \\
\hline Total monthly precipitation & $0.528 * *$ & 0.029 & 0.122 \\
\hline
\end{tabular}
relation to ignition time for green redberry juniper leaves in west Texas.

**Significant at $1 \%$ level

year. The most extensive wildfires in west Texas occurring during the latter period when the ether extract content is at the low point of the annual cycle. The greatest potential for crown fires appears to occur during this time but is probably related to moisture content of the foliage more than to ether extract content.

\section{Literature Cited}

Adams, R.P. 1970. Seasonal variation of terpenoid constituents in natural populations of Juniperus pinchotii Sudw. Phytochem. 9:397-402.

American Society for Testing and Materials. 1956. Standard methods of test for ether solubility of wood. D1108-56.

American Society for Testing and Materials. 1962. Tentative method of test for water using Karl Fisher Reagent, E203-62T.

Anderson, H.E. 1970. Forest fuel ignitibility. Fire Technology 6:312-319, 322.

Curry, J.R., and W.L. Fons. 1938. Rate of spread of surface fires in the ponderosa pine type of California. J. Agr. Res. 57:239-268.

Fons, W.L. 1946. Analysis of fire spread in light forest fuels. J. Agr. Res. 72:93-121.

Hawley, L.F. 1926. Theoretical consideration regarding factors which influence forest fires. J. Forest. 24:756-763.

Montgomery, K.R. 1976. Ether extractives and flammability of Mediterranean-type shrubs. Masters thesis, Calif. State Polytechnic Univ., Pomona.

Mutch, R.W. 1964. Ignitition delay of ponderosa pine needles and sphagnum moss. J. Appl. Chem. 14:271-275.

Philpot, C.W. 1969a. Seasonal changes in heat content and ether extractive content of chamise. USDA-FS Res. Pap. INT-61. Intermt. Forest and Range Exp. Sta., Ogden, Utah.

Philpot, C.W. 1969b. The effect of reduced extractive content on the burning rate of aspen leaves. USDA-FS Res. Note INT-92, Intermt. Forest and Range Exp. Sta., Ogden, Utah.

Philpot, C.W., and R.W. Mutch. 1968. Flammability of herbicide-treated guava foliage. USDA-FS Res. Pap. INT-54. Intermt. Forest and Range Exp. Sta., Ogden, Utah.

Rothermel, R.C. 1976. Forest fires and the chemistry of forest fuels. p. 245-259. In: Thermal Uses and Properties of Carbohydrates and Lignins, F. Shafizadeh, K.V. Sarkanen and D.A. Tillman, eds. Academic Press, New York.

Rothermel, R.C., and H.E. Anderson. 1966. Fire spread characteristics determined in the laboratory. USDA-FS Res. Pap. INT-30, Intermt. Forest and Range Exp. Sta., Ogden, Utah.

Snedecor, G.W., and W.G. Cochran. 1967. Statistical methods. Iowa State University Press, Ames.

Susott, R.A. Thermal behavior of conifer needle extractives. In preparation.

USDA, Forest Service. 1963. Annual Report, Rocky Mountain Forest and Range Exp. Sta., Fort Collins, Colo.

Wright, H.A. 1974. Range burning. J. Range Manage. 27:5-11. 